\title{
Den finansielle Udvikling i de sanderjydske landsdele top, under og efter Krigen.
}

Blandt Bilagene til den sønderjydske Realkreditkómmissions Betænkning af 4 . Marts 1926 findes en Redegørelse for den finansielle Udvikling $i$ de sønderjydske Landsdele før, under og efter Krigen med særligt Henblik paa Realkreditforholdene, som frembyder særlig Interesse, fordi der i Redegørelsen paa Grundlag af et omfattende Materiale gives en Fremstilling af, hvorledes Krigen og Genforeningen har indvirket paa vort Hovederhverv, Landbrugets økonomiske Stilling. Redegørelsen, der er udarbejdet af Amtmand Kr. Refslund Thomsen under Medvirkning fra forskellig sagkyndig Side, gengives efterstaaende med Amtmandens Samitykke.

For at komme til Klarhed over det Spørgsmaal, som det er Kommissionens Opgave at undersøge, vil det formentlig være af Interesse at have Rede paa, hvorledes Gældsforholdene indenfor Landbruget $i$ Nordslesvig specielt Prioritetsgælden, har udviklet sig under de store okonomiske Omvæltninger, som var en Følge af Krigen og Genforeningen.

Ved Aarhundredskiftet begynder en økonomisk Opgangstid, navnlig for vor Landsdels Hovederhverv, Landbruget. Det stigende Udbytte genopliver Drif- 
tigheden efter Firsernes og Halvfemsernes Stagnation, og dette i Forbindelse med den fornyede Tilgang af Landboungdom skaber en forøget Eftersporgsel efter Landejendomme. De stigende Ejendomspriser afføder atter en forøget Gældsstiftelse, som delvis hidrører fra Ejendomsoverdragelser, men for en væsentlig Del fra Laan til Iværksættelse af Fremskridt og Forbedringer i Driften. De sidste Aar for Krigen er en udpræget Byggetid, og samtidig sker der en betydelig Udvidelse af Besætningerne og en gennemgribende Forbedring af Jordkulturen.

Den hjemlige Opsparing kunde ikke stille de hertil fornodne Kapitaler til Raadighed. Den aarlige Tilvækst i de nordslesvigske Pengeinstituters Indskudsmidler beløb sig til 5-6 Millioner Mark, hvoraf noget over Halvdelen falder paa Sparekasserne. Men medens Bankerne var i stand til at løse deres Opgave uden i nævneværdig Grad at lægge Beslag paa fremmed Kapital, formaaede Sparekasserne ikke at tilfredsstille den stærke Efterspørgsel efter faste Laan fra Landbrugets Side. Til Dækning af det nordslesvigske Landbrugs Realkreditbehov krævedes derfor betydelige Kapitaltilførsler sydfra.

Den storste Rolle i denne Forbindelse spiller de to Landkreditforeninger i Kiel: "Landschaftlicher Kreditverband für die Provinz Schleswig-Holstein" og "Schleswig-holsteinische Landschaft". "Kreditverband" var oprettet i 1882 paa nordslesvigsk Initiativ, og endnu ved Krigens Udbrud havde denne Forening langt den største Del af sit Udlaan i de fire nordslesvigske Kredse. I de sidste Aar før Krigen fik ogsaa "Landschaft" en ret betydelig Tilgang af Laan fra Nordslesvig. 
Kreditforeningslaan i nordslesslesvigske Landejendomme $:^{1}$ )

\begin{tabular}{lccc} 
& Ultimo & Ultimo & Ultimo \\
Kreditforeninger & 1909 & 1911 & 1914 \\
& Mill Mk. & Mill. Mk. & Mill. Mk. \\
Kreditverhand & 35,1 & 38,4 & $54,--$ \\
Landschaft & $?$ & 16,1 & $27,-$ \\
\cline { 2 - 4 } \multicolumn{1}{c}{ Tilsammen: } & $?$ & 54,5 & $81,--$
\end{tabular}

Desuden indestod i nordslesvigske Landejendomme Laan fra Hypotekbanken "Preussische Zentralbodenkreditaktiengesellschaft “ i Berlin, Sparekasser i Holsten, Westfalen og Hannover og enkelte tyske Stiftelser og Forsikringsselskaber samt Rentegæld henholdsvis Laan i nordslesvigske Renteejendomme fra Rentebanken i Stettin, Höfebank i Kiel og Landbrugministeriet. Hvor store Midler disse Institutioner med Domicil sydfor den nuværende Grænse har stillet til Raadighed for Realkreditten i Nordslesvig, lader sig ikke med Sikkerhed oplyse. Deres samlede Beløb ved Krigens Udbrud anslaas skønsmæssig til 20 Millioner Mark.

De Laanekapitaler, som sydfra tilflød det nordslesvigske Landbrug, anvendtes for en ikke ringe Del til Indfrielse af Pantegæld til hjemlige Sparekasser og private Kreditorer og bidrog saaledes til en Forøgelse af de nordslesvigske Pengeinstitutters Virkemidler og en Forskydning i Sparekassernes Udlaan fra I. til II. Prioritet.

Gennem Nordslesvigsk Kreditforening, som oprettedes i 1910 med en indbetalt Stamkapital af 830,000

1) Tallene omfatter ogsaa Udlaanet i Tonder SønderAmt, derimod ikke i den Del af Flensborg Amt, som kom til Danmark. 
Den finansielle Ldvikling $i$ de sunderj. Landsdelr. $\quad 81$

Mark, tilfortes der desuden Landsdelen nogen Kapital nordfra, som anbragtes mod II. eller III. Prioritet i Landejendomme for at hjælpe unge, uformuende danske Landmænd i Vej. I samme Retning virkede en Del af de danske Sparekasser, som derved gjorde en værdifuld Indsats til Losning af en betydningsfuld national og social Opgave.

I de sidste 10 Aar før Krigen fandt ogsaa de smaa Andels-Spare- og Laanekasser, som tilhorte "Verband der schleswig-holsteinischen landwirtschaftlichen Genossenschaften" i Kiel, en ret betydelig Udbredelse, navnlig i Aabenraa og Sonderborg Amter. Derved paafortes der de gamle Sparekasser en Konkurrence om Sparemidlerne, som yderligere skærpedes derved, at Bankerne og de kommunale Kredssparekasser ved Oprettelse af Filialer og Agenturer søgte at drage Kapitalen til sig, samt ved Bankernes Rentepolitik.

Af fremmede Midler er endnu at nævne, hvad de i Nordslesvig oprettede Filialer af tyske Banker med Domicil sydfor den nuværende Grænse skyldte til Hovedsædet. Schleswig-holsteinische Bank i Husum havde i 1914 5, Westholsteinische Bank i Heide (nu Altona) 2 Filialer i Nordslesvig.

\begin{tabular}{|c|c|c|c|c|c|c|}
\hline \multirow{2}{*}{ Filialer af } & \multicolumn{2}{|c|}{ Indskud } & \multicolumn{2}{|c|}{$\begin{array}{c}\text { Gæld til } \\
\text { Hovedsædet }\end{array}$} & \multicolumn{2}{|c|}{$\begin{array}{l}\text { Tilgodehavende } \\
\text { hos Hovedsædet }\end{array}$} \\
\hline & $\begin{array}{l}\text { Ult. } 1913 \\
\text { lok) } \mathrm{Nk}\end{array}$ & $\begin{array}{l}\text { It. } 1914 \\
000 \mathrm{Mk} \text {. }\end{array}$ & $\begin{array}{l}\text { [ilt 191: } \\
1000 \mathrm{Mk}\end{array}$ & $\begin{array}{l}\text { lt. } 1914 \\
000 \mathrm{Mk}\end{array}$ & $\begin{array}{l}\text { [ilt. 19] } \\
\text { 1000 Mk }\end{array}$ & $\begin{array}{l}\text { t. } 19114 \\
00 \mathrm{Mk} .\end{array}$ \\
\hline $\begin{array}{l}\text { Schl. Ho st. Bank } \\
\text { og } \\
\text { Westholst. Bank }\end{array}$ & 12.120 & 16.407 & 5.616 & $38 \times 2$ & $10 \mathrm{x}$ & 671 \\
\hline
\end{tabular}

Tilsvarende Oplysninger om Schlesw.-holsteinischer Bankvereins Filial i Tonder har det des- 
værre ikke varet muligt at fremskaffe, og det er heller ikke bekendt, hvad Den tyske Rigsbank skyldte eller havde tilgode i Nordslesvig i 1914.

Bevægelsen i de nordslesvigske Pengeinstitutters Indskudsmidler for og under Krigen fremgaar af følgende Tal:

Indskud i nordslesvigske Pengeinstituter.

\begin{tabular}{|c|c|c|c|c|}
\hline Eltimo & $\begin{array}{l}\text { Spalekasser } \\
\text { Mill. Mk. }\end{array}$ & $\begin{array}{l}\text { Hjemlige } \\
\text { Banker } \\
\text { Mill. Mk. }\end{array}$ & $\begin{array}{l}\text { Filialer af to } \\
\text { tyske Banker } \\
\text { Mill. Mk. }\end{array}$ & $\begin{array}{l}\text { Andels- } \\
\text { kasser } \\
\text { Mill. Mk. }\end{array}$ \\
\hline 1905 & $63, x$ & 14,4 & & 1,3 \\
\hline 1906 & 660,2 & 16,3 & & 1.7 \\
\hline 1907 & $6 x, 7$ & 18,3 & & 2,2 \\
\hline $190 x$ & 72,1 & 19,0 & & 2,4 \\
\hline 1909 & 75.1 & 20,8 & & 2,8 \\
\hline 1910 & (“il. $\left.79,()^{*}\right)$ & 23,4 & $?$ & 3,4 \\
\hline 1911 & $-82,0$ & $26 i, 8$ & $?$ & 4,2 \\
\hline 1912 & $=\times 5,11$ & 29,0 & $?$ & $?$ \\
\hline 1913 & $-86,0$ & 30,2 & 12.1 & $?$ \\
\hline 1914 & $-89,0$ & 33.0 & 16,4 & $?$ \\
\hline 1915 & $=9 \times, 0$ & 43,5 & 19,6 & $\dot{?}$ \\
\hline 1916 & $=10 \times, 0$ & $4 !, 7$ & 26,8 & $?$ \\
\hline 1917 & $-127,0$ & 67,0 & 35,0 & ? \\
\hline 1918 & - 150 & 87,0 & 44,9 & ? \\
\hline 1919 & $-1 \times 2,()$ & $1 \times 6 i, 0$ & 100,7 & $?$ \\
\hline 1920 & $=213,0$ & $2: 30,0$ & & ? \\
\hline
\end{tabular}

Ved Verdenskrigens Udbrud kan Stillingen paa det nordslesvigske Kapitalmarked herefter opgøres saaledes:

* Fra 13is er Tallene for sparekassernes Vedkommende udfundne ved Beregning paa cirundlag af en Undersogelse af :26 storre sparekasser, som reprasenterer 87 pCt. af Indskudskapitalen. 
Den finansielle ldvikling i de sonclerj. I.andsdite.

Hjemlige Midler.

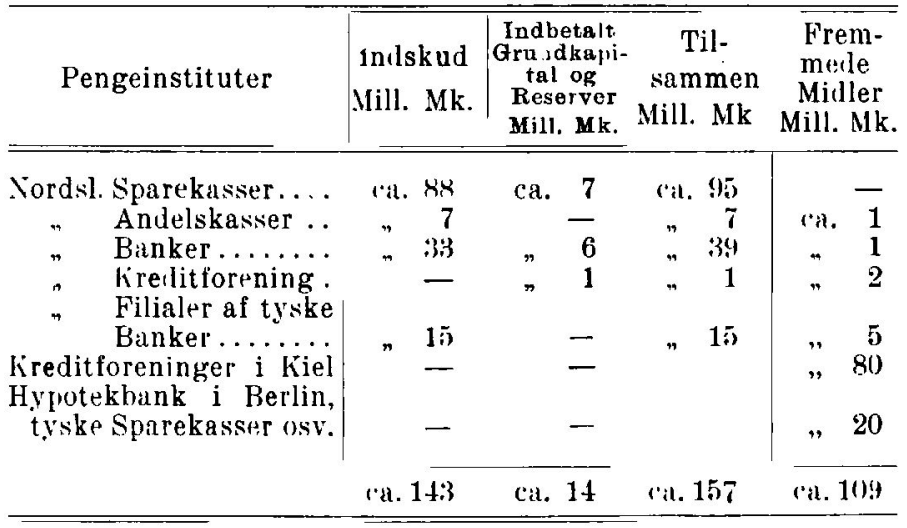

Af fremmede Midler var med en rund Sum 100 Millioner Mark anbragt mod Hypotek i Landejendomme i Nordslesvig. Derimod er det ikke bekendt, hvor stor en Del af de hjemlige Pengeinstitutters Virkemidler Landbruget har lagt Beslag paa; men man skønner, at det vil være et lignende Beløb som de fremmede Midler, ca. 100 Mill. Mk., hvoraf henved Halvdelen var Hypoteklaan fra Sparekasserne og Nordslesvigsk Kreditforening.

For 22 stcrre sparekasser, for hvilke der foreligger Oplysninger om L'dlaanet nod Hypotek i fast Ejendom, udgjorde Hypoteklaanene ca. 80 pCt. af Indskudskapitalen:

\begin{tabular}{|c|c|c|c|}
\hline Ultimo & $\begin{array}{l}\text { Sumlet } \\
\text { Indskud } \\
\text { Mill. Mk. }\end{array}$ & $\begin{array}{l}\text { Ijdlaun moll } \\
\text { Hypotek } \\
\text { Mlill. Mk. }\end{array}$ & $\begin{array}{l}\text { lldiakn mod } \\
\text { Hypotek i pCt. } \\
\text { af saml Indskud } \\
\text { p('t. }\end{array}$ \\
\hline 1913 & (ix, 0 & $\pi 4,4$ & $x(), 0$ \\
\hline 1914 & 70,2 & $5.5,8$ & 79,5 \\
\hline
\end{tabular}


Gaar man ud fra, at Forholdet mellem Indskud og Hypoteklaan er det samme for de øvrige Sparekassers Vedkommende, skulde altsaa 80 pCt. af de nordslesvigske Sparekassers samlede Indskud i 1914 eller ca. 70 Millioner Mark have været udlaant mod Pant i fast Ejendom og deraf formentlig godt 40 Millioner i Landejendomme.

Hertil kommer endnu de private Midler, som indestod i Landejendomme, hovedsagelig Restkøbesummer og Arveparter. Det er meget betydelige Kapitaler, der her er Tale om; men det er vanskeligt at danne sig et paalideligt Skøn over Størrelsen af disse Behæftelser. Bankdirektør Hübbe anslaar det samlede Beløb af private Hypoteker i Nordslesvig incl. Laan fra Kirkekasser, Stiftelser, Legater osv. til 80100 Millioner Mark. En Lndersøgelse af Grundbøgerne for 1i Landsogne, spredt over hele Nordslesvig, og for 3 Gader $i$ en nordslesvigsk Købstad har givet følgende Resultater:

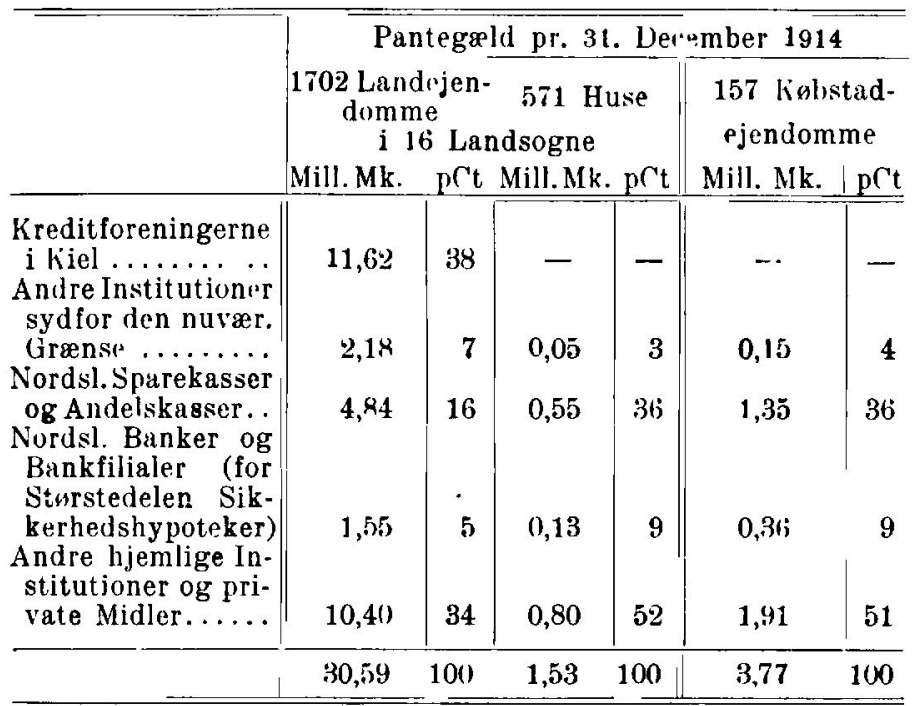


Den finansielle Lavikling $\mathrm{i}$ de sonderj. Landsdele. $\quad 85$

Med Hensyn til Behæftelsen af Landejendomme er at bemærke, at Gælden til Kreditforeningerne var relativt større i Haderslev Amt end i de øvrige nordslesvigske Amter, medens paa den anden Side Sparekasserne gjorde sig forholdsvis stærkest gældende som Realkreditinstitutter i Sønderborg Amt.

\begin{tabular}{|c|c|c|}
\hline & \multicolumn{2}{|c|}{$\begin{array}{l}\text { Kreditforeningslaan i Landejen- } \\
\text { domme i Nordslesvig ultimo } 1911\end{array}$} \\
\hline & Mill. Mk. & Forholdstal \\
\hline Haderslev Amt .... & $2 \times, 9$ & 53 \\
\hline Aabenraa Amt $\ldots \ldots \ldots \ldots$ & 7,2 & 13 \\
\hline sunderborg Amt......... & 6,5 & 12 \\
\hline \multirow[t]{2}{*}{ Tsinder Amt............. } & 11,9 & 22 \\
\hline & 54,5 & 100 \\
\hline
\end{tabular}

Prioritetsgæld i Landejendomme i

7 Sogne i Haderslev og 3 Sogne i Sunderborg Amt ultimo 1914

Haderslev Amt Sunderborg Amt

\begin{tabular}{|c|c|c|c|c|}
\hline \multirow{3}{*}{$\begin{array}{l}\text { Kreditforeningerne i kiel... } \\
\text { Andre Institutioner sydfor } \\
\text { den nuværende (irænse... } \\
\text { Nordslesvigske Sparekasser } \\
\text { ng Andelskasser ......... }\end{array}$} & 6,10 & 45 & 2,43 & 29 \\
\hline & 0,93 & 7 & 0,33 & 4 \\
\hline & $1,30)$ & 10 & 2,20 & 27 \\
\hline Nordslesvigske Banker og & & & & \\
\hline Bank-Filialer ........... & 0,66 & 5 & 0,44 & 5 \\
\hline $\begin{array}{l}\text { Andre hjemlige Institutioner } \\
\text { "g private Midler ........ }\end{array}$ & 4,39 & 33 & 2,91 & 35 \\
\hline & 13,38 & 100 & 8,31 & 100 \\
\hline
\end{tabular}

For saa vidt, som man tør drage Slutninger fra dette Materiale til hele Landsdelen, har de private 
Hypoteker for Krigen udgjort en Tredjedel af den samlede i Landejendomme indestaaende Gæld og Halvdelen af Pantegælden i Kobstadejendomme og Huse paa Landet. Den indprotokollerede Gæld til Bankerne, mest i Form af Sikkerhedshypoteker, fordeler sig ligeledes jæunt paa de forskellige Amter, nemlig nued 5 pCt. for Landejendomme og 9 pCt. for Kobstadejendomme og Huse paa Landet. Med Hensyn til Kreditforeninger og andre Institutioner nied Domicil sydfor den nuværende Granse er der derimod en ret betydelig Forskel at notere, idet Laanene fra disse Institutioner i Haderslev Amt udgør over Halvdelen af den paa Landejendommene indprotokollerede Gæld, men kun en Tredjedel i Sønderborg Amt. Her falder til Gengrld godt en Fjerdedel af den samlede Pantegæld paa Sparekasserne mod kun en Tiendedel i Haderslev Amt.

Det nordslesvigske Landbrugs samlede Prioritetsgæld kan herefter omtrentlig opgores saaledes:

Hypoteklaan sydfra

Nordslesvigske Sparekasser og Andelskasser

Nordsl. Banker og Bankfilialer

Andre hjemlige Institutioner og private ca. 9.j Mill. Mk.

$\begin{array}{lll}-40 " 1 & \\ - & 10 & \end{array}$

- $75 "$

Ialt ca. 2:0 Mill. Mk.

Krigen gjorde en brat Ende paa den blomstrende økonomiske Udvikling, som karakteriserer de sidste Fredsaar.

Det første Krigsaar bragte ingen væsentlige Forskydninger i det nordslesvigske Landbrugs Økonomi. 
Den rige Høst, som stod paa Markerne i August 1914, blev bjerget og Driften holdt i Gang. Selv om det skortede paa Driftsledere og Arbejdere, havde Landbruget i Kvinderne og de gamle og helt unge Mænd og Børnene en Reserve af Arbejdskraft, som gjorde nogenlunde Fyldest, og Jorden var gennemgaaende $\mathbf{i}$ en saa god Godningskraft og Renhedstilstand, at den kunde give Udbytte ogsaa uden tilstrækkelig Behandling og Godskning.

Man kom saaledes, tvunget af Omstændighederne, ind paa en Rovdrift, som efterhaanden forvandlede en Del af de i Jorden nedlagte Kapitalværdier til Pengekapitaler, og denne Udvikling fremskyndedes ved, at det til Opretholdelse af Folkeernæringen blev nødvendigt at gore Indgreb i Besætningerne og Produktbeholdningerne, og at der hverken stod indført Kraftfoder eller Kunstgødning til Raadighed. Allerede paa et tidligt Tidspunkt blev Svinebesætningerne meget stærkt reducerede, og eftersom Tiden gik, tyndede Tvangsafleveringerne ogsaa slemt ud i Kvagbesatningerne.

Denne Mobiliseling af Realværdierne afspejler sig i de nordslesvigske Pengeinstituters Regnskaber. I det forste Krigsaar er der ingen nævneværdige Forandringer at spore, Opgorelserne pr. ultimo 1914 udviser $i$ det store og hele kun normal Tilgang i Indskudsmidlerne. Men fra 1915 sætter den begyndende Likvidation sit Præg paa Sparekassernes og navnlig Bankernes Regnskaber.

Da Priserne paa Levnedsmidler blev holdt nede paa et Niveau, som ikke levnede Landbruget nogen Fortjeneste, men nærmest gjorde den almindelige Drift urentabel, kan man gaa ud fra, at den stærke 
Stigning i Pengeinstituternes Indskud under Krigen ganske overvejende skyldes Mobiliseringen af de $i$ Landbruget bundne Realkapitaler. Kun de forholdsvis faa Landmænd, som slog ind paa Dyrkningen af Grontsager eller underhaanden solgte Levnedsmidler til Aagerpriser, profiterede af Krigsforholdene. Forst mod Krigens Slutning, da den almindelige Moral slappedes og Pengene sank i Værdi, faar den stedse stigende Strøm af Indlaan i Sparekasser og Banker delvis Karakteren af Krigsgevinst og Inflationsværdier. I hvilket Omfang dette er Tilfreldet, er det selvfølgelig umuligt at paavise.

Ogsaa indenfor Handel og Haandværk foregaar der i Krigsaarene en tilsvarende Udvikling. Driftskapitalen gøres flydende, idet Varebeholdningerne svinder og efterhaanden forvandles til Penge. Man skal dog ikke komme ind paa en nærmere Udredning af disse Forskydninger, dels fordi Forholdene ligger meget forskelligt fra Branche til Branche og dels fordi det, udtrykt i Penge, formentlig ikke betyder nær saa meget, som den tvungne Rovdrift indenfor Landbruget.

Hvorledes anvender Landbruget nu de betydelige Pengemidler, som bliver disponible? Størstedelen gaar enten direkte eller ad Omveje ind i Pengeinstituterne som Indskud, derimod ikke, som man kunde vare tilbøjelig til at antage, som Afdrag paa Gæld. Bønderne har aabenbart villet holde de frigjorte Kapitaler disponible til Genrejsning af Driften efter Krigens Slutning.

I 18 større Sparekasser, for hvilke der foreligger fuldstændige Oplysninger fra 1913 til 1920, har Bevægelsen paa de forskellige Konti været saaledes: 
Den finansielle Cdvikling i de sınderj. Landsdele.

\begin{tabular}{|c|c|c|c|c|}
\hline Ultimo & $\begin{array}{l}\text { Indskud } \\
\text { Mill. Mk. }\end{array}$ & $\begin{array}{l}\text { Collaun } \\
\text { mod } \\
\text { Hypotek } \\
\text { Mill. Mk. }\end{array}$ & $\begin{array}{c}\text { Lidlaan mod } \\
\text { liældsbevis } \\
\text { Mill Mk. }\end{array}$ & $\begin{array}{c}\text { Banktil- } \\
\text { godehavende } \\
\text { Mill. Mk. }\end{array}$ \\
\hline 1913 & 61,7 & 50,0 & 10,4 & 0,7 \\
\hline 1914 & 63,7 & 51,3 & 10,8 & 1,2 \\
\hline 1915 & $70, \bar{j}$ & 51,4 & 12,6 & 3,8 \\
\hline 1916 & 79,3 & $48, \overline{5}$ & 15,8 & 6,1 \\
\hline 1917 & 89,4 & 46,4 & 20,4 & 8,8 \\
\hline 1418 & 104,2 & 44,4 & $2.5,5$ & 13,5 \\
\hline 1919 & 125,1 & 20,3 & 31,5 & 46,5 \\
\hline 1920 & $14 x, 4$ & 7,3 & 33,3 & 77,3 \\
\hline
\end{tabular}

Indtil Udgangen af 1918 er der en langsom Nedgang i Ldlaanet mod Hypotek, men en stærk Stigning i Udlaan mod Groldsbevis. Dette sidste maa ikke opfattes som Udtryk for en stigende Laanetrang i Befolkningen, men skyldes særlige Forhold, navnlig Laan til Kommuner. De lose Gældsforhold afvikles efterhaanden, Kobmændenes og Haandværkernes Bogfordringer gaar ind, og ogsaa disse Penge havner, da de kun i ringe Grad kan finde Anvendelse i Forretningen, i Pengeinstituterne. Man mener ogsaa, at en Del Landmænd allerede i Krigens Tid har begyndt at opkøbe Kieler-Pantebreve til Dækning af deres Kreditforeningsgæld uden dog at benytte dem til Indfrielse af Laanet.

Efter Vaabenstilstanden skifter Billedet atter.

Markinflationen og Udsigten til Genforening med Danmark stillede Erhvervene og Pengeinstituterne overfor nye Problemer, som der maatte tages Stilling til.

Aaret 1919 karakteriseres ved en hidtil ukendt Pengerigelighed, som driver Indskudene i Sparekasser og Banker op i fantastiske Højder. Denne Over- 
flod af Penge skyldes dels det stærkt stigende Prisniveau, dels Valutatransaktioner. Nu afvikles ogsa: den faste Gald baade til Kreditforeninger, Sparekasser og private Kreditorer. Midlerne hertil laanes for en vasentlig Del hos Banker i det gamle Land, og derfor tager Likvidationen af de faste Gældsforhold forst Fart i Grænseegnene for derefter at brede sig til hele Landsdelen. I mange Sparekasser indfriedes over to Tredjedele af Hypoteklaanene i Lobet af et Aar, og samtidig var de private Kreditorer, som fik deres Laan tilbagebetalt, henviste til at sætte Pengene i Sparekasser og Banker.

Overfor denne enorme Tilgang af Kapital, som yderligere ogedes ved Kapitalflugten sydfra, maatte de nordslesvigske Pengeinstituter se sig om efter nye Anbringelsesmuligheder. Allerede i de sidste Krigsaar havde Sparekasserne maattet indsætte en ikke ubetydelig Del af deres disponible Midler paa Folio i Bankerne, og efter Vaabenstilstanden antager sparekassernes Indlaan i Bankerne et saadant Omfang, at disse hen paa Sommeren 1919 nægter at modtage flere Penge. Sparekasserne maa derfor ligesom Bankerne lade deres overskydende Midler gaa sydpaa som Indskud i tyske Storbanker eller anbringe dem som Laan til tyske Kommuner eller i tyske Værdipapirer.

Det er let nok at se nu, at denne forcerede Likvidation af Gældsforholdene, som for en væsentlig Del foregik ved Hjælp af Kronelaan, har været meget uheldig, og Sparekasserne og Bankerne gjorde allerede paa et tidligt Tidspunkt Forsøg paa at hæmme denne Trafik eller i hvert Fald begrænse den til Indfrielse af Pantegæld til tyske Pengeinstitutter, dels af Hensyn til de Vanskeligheder, den beredte Penge- 
institutterne, dels med en fremitidig Valutaregulering for $\emptyset j$. Men naar man satter sig ind i Grundejernes Stilling og betronker, at det var den almindelige Mening, at Marken vilde rette sig igen, naar Forholdene atter blev normale i Tyskland, kan man ikke fortænke de nordslesvigske $B$ onder $i$, at de sogte at udnytte den lave Markkurs til Konvertering af deres Greld. Frygten for en almindelig Valutaregulering paa Debitorernes Bekostning har ligeledes virket som en spore til hurtigst muligt at bringe de gamle Gældsforhold ud af Verden. Man kan derfor forstaa, at Bonderne indlod sig paa disse Transaktioner. De har ikke søgt Spekulationen, men er bleven drevet ind $\mathrm{i}$ den. Der var forøvrigt ikke mindre Spekulation og Risiko ved at vente end ved at handle. De Markejere, som i Tillid til Markkursens Stigning eller en Valutaregulering til Pari har lad'et deres Mark staa hen, har haft endnu mindre Glæde af deres Passivitet end Grundejerne af deres Hastværk med at faa Kronelaan.

Den Valutaregulering, vi fik i Henhold til Lov Nr. 297 af 28. Juni 1920, svarede ikke til Markkreditorernes Forventninger. Navnlig ansaa man det for en stor Uretfærdighed, at Debitorerne fik Lov til at beholde den Gevinst, som de havde paa Kreditorernes Bekostning. Men under Indtryk af de følgende Aars okonomiske Udvikling lader Kravet om Skadesløsholdelse af Kreditor ved Debitor sig ikke opretholde, og selv Hovedtalsmanden for Markejernes Krav, $\mathrm{Hr}$. Direktør Hübbe, maa i Dag indrømme, at Grundejerne, som Forholdene har udviklet sig, ikke vilde have kunnet bære denne Byrde. Herom hedder det i Haderslev Banks Jubilæumsskrift: "Set fra et økonomisk Standpunkt vilde Debitor $i$ de fleste Tilfælde sikkert 
heller ikke mere vare i Stand til at holde Kreditor skadesløs, da en meget stor Procentsats af Grundejerne i Mellemtiden har faaet saa store Hæftelser paa Ejendommene, at en Tillagsbelastning af den her nævnte Art vilde trykke dem fuldstændig i Knæ«.

Det maa derfor hilses med Taknemlighed, at Staten paatog sig hele Byrden ved Valutareguleringen. Denne tilførte Landsdelen $44^{1} / 2$ Million Kroner i Kapitalerstatning og aarlige Rentetilskud til en Kapitalværdi af 14 Millioner Kr. En betydelig Del af Kapitalerstatningen indgik som Indskud $\mathrm{i}$ de sønderjydske Banker, der som Følge af, at Staten havde stillet anselige Kronebeløb til deres Raadighed, straks havde kunnet begynde en betydelig Udlaansvirksomhed, medens Sparekasserne var fuldstændig lammet efter Markmiseren.

$\mathrm{Nu}$ bagefter kan man ligeledes se, at det var en Fejl, hvad der dengang blev anset og paaskønnet som en særlig Begunstigelse, at Ansøgerne om Valutagodtgorelse fik Lov til at beholde deres Mark til en Kurs af $71_{4}$. Da saa godt som alle disse Markkapitaler er bleven værdiløse, er der alene paa denne Konto tabt 15-20 Millioner Kroner. Og paa samme Maade gik det med Størstedelen af de ovrige Markformuer i Sønderjylland. Folk kunde ikke blive rede til at skille sig af med dem, medens de endnu havde nogen Værdi, og endida daarligt nok bekvemme sig til at benytte dem til Betaling af Gæld. Dertil vilde man hellere laane Kroner i det gamle Land.

De fleste Kronelaan er stiftede paa en Tid, da Kursen var mellem 30 og 40. De blev optaget i kongerigske Banker, ganske overvejende mod Veksel og ved Mledvirkning af sønderjydske Pengeinstituter, 
som endosserede Vekslerne. For at tilvejebringe en Oversigt over Omfanget af disse Laan foretog "Udvalget for Afhjælpning af de med Kronemøntens Indforelse i Sønderjylland forbundne Vanskeligheder" i Januar 1920 en L'ndersøgelse, som gav følgende Resultat:

\section{Kronelaan ultimo 1919.}

\begin{tabular}{|c|c|c|c|}
\hline & \begin{tabular}{|c|}
134 Banker \\
og \\
Sparekaasser \\
Mill. Kr.
\end{tabular} & $\begin{array}{c}211 \text { Banker } \\
\text { og Spare- } \\
\text { kasser } \\
\text { Mill. Kir. }\end{array}$ & $\begin{array}{c}66 \text { Banker } \\
\text { og Sparekasser } \\
\text { Mill Kr. }\end{array}$ \\
\hline $\begin{array}{l}\text { Veksler.............. } \\
\text { Kassekredit .......... } \\
\text { Laan mod liaution ell. } \\
\text { Haandpant .......... }\end{array}$ & $\begin{array}{r}32,34 \\
2,77\end{array}$ & $\begin{array}{l}0 \\
0\end{array}$ & $\begin{array}{c}\text { ingen 0plysn. } \\
"\end{array}$ \\
\hline Samlet Laanesum... & $40, \times 3$ & 0 & \\
\hline
\end{tabular}

Renten incl. Provision var, for saa vidt som den er oplyst, gennemgaaende $7^{1 / 2}-8$ pCt. p. a. Men blandt de Pengeinstituter, som ikke har givet Oplysninger, vil der findes adskillige Banker, navnlig i Nærheden af Grænsen, som har taget indtil $12 \mathrm{pCt}$. Desuden blev der optaget Kronelaan hos Privatfolk, delvis til Aagerrenter.

En stor Del af de Kapitaler, som ved Krigstidens Rovdrift var unddraget Landbruget, er ved Markens Sammenbrud gaaet tabt, og Genrejsningen og Omlægningen af Driften efter Genforeningen krævede saa stort et Arbejde og slugte saa store Summer, at der derved paaførtes Landbruget en betydelig Forøgelse af dets ved Konverteringen fra Mark til Kroner stærkt reducerede Gæld. I samme Retning virkede en hel Række af uheldige Omstændigheder. Genforeningen trak længere $u d$, end man havde regnet med. Der 
lub derfor store Vekselrenter paa Kronelaanene. Kurserne paa slesvig-holstenske Pantebreve blev ved den stærke Eftersporgsel fra Nordslesvig til Indfrielse af Kreditforeningslaanene drevet op i en Kurs af 120, og da de danske Kreditforeninger i August 1920 begyndte at optage Virksomheden i sonderjylland, stod Kurserne paa deres Obligationer i 7\%. Bestrabelserne for at bringe Ejendommene paa Fode igen efter Krigens Vanrogt har ligeledes paa mange Maader været ledsagede af Lheld og tabbringende, idet enten $\mathrm{L}^{\mathrm{d}} \mathrm{d}$ byttet eller Priserne paa Salgsprodukterne ikke svarede til de anvendte Produktionsomkostninger. I Tiden mellem Vaabenstilstanden og Genforeningen havde de nordslesvigske Bonder tildels Udgifter i Kroner og Indtagter i Mark. I Foraaret 1920 indkøbtes Kunstgedning og Saakorn til haje Priser i Danmark, Saakornet red Falleslandboforeningens Medvirkning og paa Kredit til Efteraaret. Men da Efteraaret kom, faldt Priserne. I 1921 havde vi den værste Torke, som vi har oplevet i Mands Minde, og den virkede paa Grund af Jordens daarlige Kultur- og Renhedstilstand ulige mere olelæggende heinede end i let gamle Land. Paa den lette Jord avledes der praktisk talt intet, og navnlig Græsserne led overordentlig store Tab. I det Aar fik mange sonderjydske Landmænd et Knæk, som de siden ikke har forvundet. I $1922 \mathrm{kom}$ det store Prisfald som Følge af Kronestigningen. I 1923 var Sommeren meget vaad og Høsten derfor saa sen og vanskelig, at en Del Korn blev staaende paa Marken og meget bjerget $i$ en daarlig Tilstand. 11925 har Deflationen - ligeson i 1922 - trykket Priserne saa stærkt, at Resultatet tiltrods for et udmarket Hostudbytte for 
de fleste Landbrugere er bleven et betydeligt Driftsunderskud, og samtidig er Landsdelen - for anden Gang siden Genforeningen - bleven hærget af Mundog Klovesygen; som har paafort Landbruget meget alvorlige Tab.

Dertil kommer, at det har vist sig vanskeligere, end man havde regnet med, at bringe Jord og Besætninger op paa fuld Ydeevne. Dette gælder ikke mindst om Mælkeydelsen, som var gaaet meget langt ned under Krigen. Forst i 192' er Mælkemangden pr. Ko naaet op paa samme Hnjde som i 1913.

Et Latryk for, hvad der er sat ind paa at bringe Produktionen paa Fode ig̣en, har vi i folgende Tal:

Husdyrbestanden.

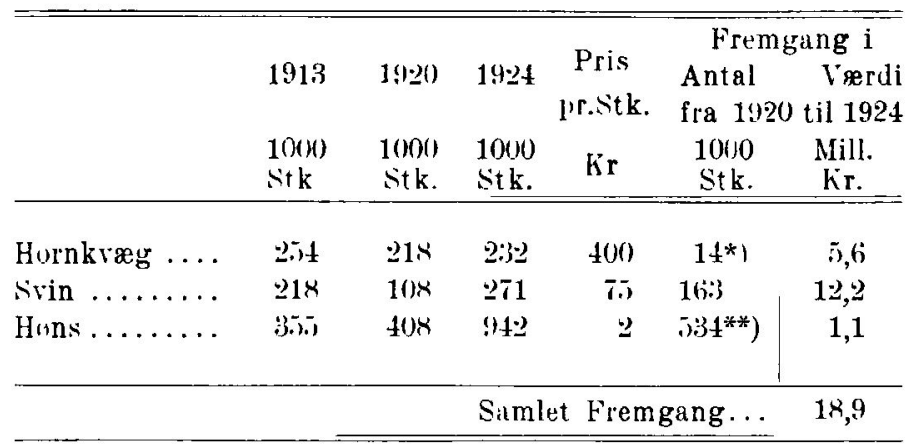

For Hestenes Vedkommende har der været en lille Tilbagegang fra 1920 til 24. (ca. 2000 Stk.)

* Hele Flemgangen falder paa Malkekwerne.

*) Af Forngelsen falder en Del paa Ikke-Iandbrug. 
Indleveret Mælkemængde paa 142 sønderjydske Mejerier.

\begin{tabular}{|c|c|c|c|}
\hline & \multirow{2}{*}{$\begin{array}{c}\text { Mælke- } \\
\text { mængde ialt } \\
\text { Mill. kg }\end{array}$} & \multicolumn{2}{|c|}{ Mælkemængde pr. Ko } \\
\hline & & $\mathrm{kg}$ & Forholdstal \\
\hline 1913 & ca. 184 & 26444 & 100 \\
\hline 1919 & , 40 & ? & ? \\
\hline 1920 & , 110 & $14 \cdot 2 \cdot 2$ & $5 B$ \\
\hline 1921 &, 14.7 & $1 \times 20$ & 69 \\
\hline 1922 & 170 & $20 t i 0$ & 78 \\
\hline 1923 & 20.5 & $24: 31$ & 92 \\
\hline $19 \div 4$ & 2.3 .5 & 26561 & 100 \\
\hline
\end{tabular}

Høsten.

\begin{tabular}{|c||c||}
\hline \hline & $\begin{array}{c}\text { Hostudbytte } i \\
\text { Millioner Foderenheder }\end{array}$ \\
\hline 1920 & 290 \\
1922 & 390 \\
1923 & 470 \\
1924 & 490 \\
\hline
\end{tabular}

Det er sandsynligt, at Opgørelsen for 1920 ligger for lavt, da man i Krigens Tid - af Frygt for Udskrivninger - havde vænnet sig til at skønne lavt. Men Forøgelsen af Høstudbyttet fra 1920 til 1924 udgør mindst 100 Millioner Foderenheder og repræsenterer en Værdi af 10-15 Millioner Kroner. Dette Resultat er naaet ved en bedre Jordbehandling, 
Grundforbedring og navnlig ved forøget Anvendelse af Kunstgørdning.

Men Produktionen skulde ikke alene sættes op efter Krigstidens Nedgang, den skulde tillige delvis lægges om efter de nye Afsætningsvilkaar, hvilket ligeledes har nødvendiggjort en betydelig Anvendelse af Kapital. Svineavlen efter dansk Mønster krævede saaledes baade Udvidelse af Staldene og Opførelse af moderne Slagterier. Samtidig har Landsdelens Elektrificering lagt Beslag paa store Kapitaler, alt indbefattet ca. 50 Millioner $\mathrm{Kr}$.

Ogsaa indenfor Kvægavlen maatte man tilpasse sig efter de nye Forhold og ligesom i det gamle Land lægge Hovedvægten paa Mælkeproduktionen. Tidligere havde det sønderjydske Landbrug med Afsætningen sydpaa for Øje tillige været indstillet paa en betydelig Kødproduktion, for hvilken de naturlige Betingelser var særdeles gunstige, navnlig $i$ den vestlige Del af Landet. Der har paa dette Omraade gjort sig nogen Famlen gældende: en Del er gaaet over fra Korthorn til Malkekvæg, men det store Flertal har søgt at oparbejde Korthornsbesætningernes Mælkeydelse med Bibeholdelse af Opdræt. Omlægning af Besætningen er forbundet med ikke ringe Omkostninger, og Kadproduktionen har, som allerede nævnt, i flere Aar bragt meget betydelige Tab. I 1921 og 25 kunde Fedekvæget ved Salg i Efteraaret ikke indbringe, hvad det havde kostet som magert i Foraaret.

Dertil kommer Forholdenes hele ekstraordinære Karakter og den af de stadige Svingninger i Pengenes Værdi betingede Usikkerhed. Inflationen og den 
lette Adgang til Penge i 1919 og 1920 fristede til Udvidelse af Forbruget og til dristige Dispositioner, som senere bragte Tab og dermed en Forogelse af Gælden og Rentebyrden. Det samme gentager sig under den ny Inflation i 1923 og 24. De berettigede Bestræbelser for at bringe Produktionen op paa Højde med Landbruget i det gamle Land forceredes frem af Inflationsaarenes Prisstigning, som syntes at give Løfte om et godt Udbytte. Men naar Forbedringerne var gennemfort, kom Deflationen og nedsatte Værdien og Udbyttet af den anvendte Kapital, medens Gælden forblev uformindsket.

I al Almindelighed kan man sige, at Landsdelens og specielt Landbrugets okonomiske Genrejsning har krævet større Ofre, end det ved Genforeningen var til at forudse, saaledes at Resultatet er bleven en stærk Forøgelse af Landbrugets Gæld fra Aar til Aar.

Der er af Kommissionen indsamlet et meget betydeligt Materiale til Belysning af Landbrugets Gældsforhold. Idet man med Hensyn til Enkeltheder vedrørende disse Undersøgelser her skal nøjes med at henvise til Tabellerne og de disse ledsagende Bemærkninger, skal man forsage at give et sammentrængt Billede af Gældsforholdene under Benyttelse af dette Materiale og de iøvrigt foreliggende Oplysninger:

Tilvæksten i Kredit- og Hypotekforeningsgælden i sønderjydske Landejendomme fremgaar af følgende Tal: 
Kredit- og Hypotekforeningernes Udlaan i Landejendomme (Hovedstol)

\begin{tabular}{|c|c|c|c|c|c|c|}
\hline & $\begin{array}{r}\overline{s 1 / 3} \\
1921 \\
\text { Mill. } \\
\text { Kir. }\end{array}$ & $\begin{array}{l}31 / \mathrm{s} \\
1922 \\
\text { Mill. } \\
\text { Kr. }\end{array}$ & $\begin{array}{c}31 / 8 \\
1923 \\
\text { Mill. } \\
\text { Kr. }\end{array}$ & $\begin{array}{c}31 / \mathrm{s} \\
1924 \\
\mathrm{Mill} . \\
\mathrm{Kr} .\end{array}$ & $\begin{array}{l}81 / 8 \\
1925 \\
\text { Mill. } \\
\text { Lir. }\end{array}$ & $\begin{array}{r}91 / 12 \\
1925 \\
\text { Mill. } \\
\mathrm{Kr} . \\
\end{array}$ \\
\hline lireditforeninger: & & & & & & \\
\hline $\begin{array}{l}\text { Sonderjyllands...... } \\
\text { Vest- og sunderj. }{ }^{1} \text {.... } \\
\text { Jydsk Husmands..... }\end{array}$ & $\begin{array}{r}40,8 \\
7,0 \\
1,1\end{array}$ & $\begin{array}{r}72,0 \\
20,0 \\
9,1\end{array}$ & $\begin{array}{l}88,9 \\
26,0 \\
14,0\end{array}$ & $\begin{array}{l}9 \times, 1 \\
30,5 \\
17,2\end{array}$ & $\begin{array}{r}10, \pi, 9 \\
3: 3,5 \\
20,1\end{array}$ & $\begin{array}{r}112,2 \\
36,0 \\
22,4\end{array}$ \\
\hline Tilsammen... & $4 \times, 9$ & 101,1 & $12 \times, 9$ & $14 \pi, 8$ & 159,5 & $170,6^{\circ}$ \\
\hline $\begin{array}{l}\text { Hypotekforeninger: } \\
\text { Jydsk Land. ....... } \\
\text { Husmands . . . . }\end{array}$ & $\begin{array}{l}0,7 \\
-\end{array}$ & $\begin{array}{l}2,5 \\
0,3\end{array}$ & $\begin{array}{l}2,8 \\
0,4\end{array}$ & $\begin{array}{l}2,9 \\
0,4\end{array}$ & $\begin{array}{l}3,4 \\
0,4\end{array}$ & $\begin{array}{l}3,9 \\
0,9\end{array}$ \\
\hline Tilsammen... & 0,7 & 2.8 & 3,2 & 3,3 & $3, \times$ & 4,4 \\
\hline $\begin{array}{c}\text { Kredit- og Hypotek- } \\
\text { foreninger Ialt..... }\end{array}$ & 49,6 & 103,9 & 132.1 & $1+\div, 1$ & 1633,3 & $17.5,0$ \\
\hline
\end{tabular}

Til ovenstaaende Oversigt bemærkes, at Tallene for Jydsk Husmandskreditforening og Hypotekforeningerne tillige omfatter Laan i jordløse Huse. Naar disse Laan bringes i Fradrag med 7 Millioner Kr., andrager det sønderjydske Landbrugs Gæld til Kreditforeninger og Hypotekforeninger pr. 31. December 192516 Millioner Kr. i Hovedstol, og Restgælden vil være ca. 2 Millioner mindre end Hovedstolen, altsaa 166 Millioner Kr. Dette Tal stemmer ret godt overens med Resultatet af den af Statistisk Departement foretagne Undersøgelse af Gældsforholdene i Landdistrikterne i de sønderjydske Landsdele, og naar Hensyn ta-

1) Tallene for Den vest- og sonderjydske Kreditforenings Udlaan pr. 31. Marts er udfundne ved Beregning, da Regnskabsaaret $i$ denne Forening filger Kalenderaaret. 
ges til, at denne Undersøgelse er foretaget pr. 15. Oktober og kun omfatter $90-95$ pCt. af Landejendommene. Dette er i endnu storre Grad Tilfældet, naar samtlige Ejendomme i Landdistrikterne tages under et.

Ved Udgangen af Aaret 1925 udgjorde den samlede Kredit- og Hypotekforeningsgæld i de sønderjydske Landsdele 224 Millioner Kroner (Hovedstol), som fordeler sig med følgende Beløb paa de enkelte Foreninger:

Sønderjyllands Kreditforening $\ldots \ldots \ldots \ldots$ 126,3 Mill. Kr. Vest- og sonderjydsk Kreditforening ....... 36,0 " " Husmandskreditforeningen $\ldots \ldots \ldots \ldots \ldots, 22,4$ » Ny jydske horbstadkreditforening ......... 18,3 " " Jydsk Grundejer Kreditforening $\ldots \ldots \ldots$ 11,0 » Kreditforeningen for industrielle Ejendomme 2,0 Ialt .. 216,0 Mill. Kr.

Jydsk Hypotekforening ............... 3,6 » Jydsk Landhypotekforening $\ldots \ldots \ldots \ldots \ldots, 3,9$ " Husmandshypotekforeningen $\ldots \ldots \ldots \ldots \ldots, 0,5$ »

Ialt $\ldots . .8,0$ Mill. $\mathrm{kr}$. Wreditforeninger og Hypotekforeninger ialt 224,0 Mill. kr.

Dertil svarer en Restgæld paa ca. 221 Mill. Kr.

Det sønderjydske Landbrugs Kreditforeningsgæld er mere end fordoblet siden 1914. Dette Forhold er dog ikke Udtryk for Tilvæksten i Landbrugets samlede Pantegæld, idet der indenfor andre Kreditorgrupper er en endog meget betydelig Nedgang at notere. Sparekassernes Hypoteklaan er saaledes reducerede til en Tredjedel i Sammenligning med Tiden før Krigen, og rle private Pantekreditorer spiller heller ikke paa langt nær den Rolle som i 1914. 
Den finansielle Ldvikling i de sonderj. Landsdele. 101

Til Oplysning om de sønderjydske Sparekassers Virksomhed i Tillen efter Genforeningen tjener følgende tabellariske Oversigt:

\begin{tabular}{|c|c|c|c|c|c|c|}
\hline & \multirow{3}{*}{$\begin{array}{l}\text { Samlet } \\
\text { Indskud } \\
1000 \mathrm{Kr} \text {. }\end{array}$} & \multirow{3}{*}{$\begin{array}{c}\text { Re- } \\
\text { server } \\
1000 \\
\text { hr. }\end{array}$} & \multicolumn{2}{|c|}{ Cdlaan } & \multirow{3}{*}{ 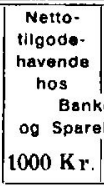 } & \multirow{3}{*}{ 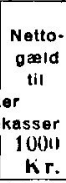 } \\
\hline & & & $\begin{array}{c}\text { mod } \\
\text { Hy - } \\
\text { potek }\end{array}$ & $\begin{array}{c}\text { mod } \\
\text { Galds } \\
\text { bevis }\end{array}$ & & \\
\hline & & & $1000 \mathrm{Kr}$. & $1000 \mathrm{Kr}$. & & \\
\hline $31 / 3 \quad 1921$ & & & & & & \\
\hline Aabenraa Amt... & $27 \pm x$ & 8 & 1793 & 393 & 566 & \\
\hline Haderslev Amt... & 4595 & 235 & 2496 & 2131 & 56 & \\
\hline Sunderborg Amt.. & 4441 & 25 & 2197 & 956 & 1024 & \\
\hline Tonder Amt ..... & 2246 & 96 & $2 \times 7$ & 1647 & 187 & \\
\hline $\begin{array}{c}\text { De sønderjydske } \\
\text { Amter ialt...... }\end{array}$ & 14010 & 364 & 6773 & 5127 & 1833 & \\
\hline $31 / 31922$ & & & & & & \\
\hline Aahenraa Amt... & 3274 & 23 & $2 \div 89$ & 483 & 577 & \\
\hline Haderslev Amt... & 9489 & $5 \% 3$ & 5060 & 3421 & 368 & \\
\hline Sonderborg Amt.. & 8043 & 101 & 5129 & 1757 & 364 & \\
\hline Tonder Amt & 3748 & 128 & 868 & 2776 & 127 & \\
\hline $\begin{array}{c}\text { De sonderjydske } \\
\text { Amter ialt ..... }\end{array}$ & $245 \pi 4$ & $80 \bar{j}$ & 13346 & 8837 & $14: 36$ & \\
\hline $31 / 31923$ & & & & & & \\
\hline Aabenraa Amt... & 4086 & 51 & $2 \div 47$ & 739 & 654 & \\
\hline Haderslev Amt... & 10735 & 647 & 7801 & 3985 & 273 & \\
\hline Sanderborg Amt.. & 10321 & 209 & 7367 & 1775 & 1253 & \\
\hline Tunder Amt .... & 4290 & 202 & 1307 & 3288 & 195 & \\
\hline $\begin{array}{c}\text { De sunderjydske } \\
\text { Amter ialt .... }\end{array}$ & $294: 32$ & 1109 & 19022 & $97 \times 7$ & 2375 & \\
\hline
\end{tabular}




\begin{tabular}{|c|c|c|c|c|c|c|}
\hline & \multirow{3}{*}{$\begin{array}{l}\text { Samlet } \\
\text { Indskud } \\
1000 \mathrm{Kr} \text {. }\end{array}$} & \multirow{3}{*}{$\begin{array}{c}\text { Re- } \\
\text { server } \\
1000 \\
\text { hr. }\end{array}$} & \multicolumn{2}{|c|}{ L'dlaan } & \multirow{3}{*}{$\mid \begin{array}{c}\text { Netto- } \\
\text { tilgode- } \\
\text { havande } \\
\text { hos } \\
\text { Banke } \\
\text { og Sparek } \\
11100 \mathrm{~K} \mathrm{r} .\end{array}$} & \multirow{3}{*}{$\begin{array}{l}\text { Netto- } \\
\text { geild } \\
\text { til } \\
\text { rerser } \\
10(30 \\
\mathrm{Kr} \text {. }\end{array}$} \\
\hline & & & $\begin{array}{c}\text { mod } \\
\text { Hy- } \\
\text { potek }\end{array}$ & $\begin{array}{l}\text { mod } \\
\text { (imlds- } \\
\text { bevis }\end{array}$ & & \\
\hline & & & $1000 \mathrm{Kr}$. & $1000 \mathrm{Kr}$. & & \\
\hline $31 / 3 \quad 19: 4$ & & & & & & \\
\hline Aabenraa Amt... & 3168 & 72 & $255 \%$ & 937 & & 15 \\
\hline Haderslev Amt ... & 10881 & 695 & 6148 & 41368 & & 1.50 \\
\hline Sunderborg Amt.. & $1078: 3$ & 325 & 8081 & 1933 & 56 & \\
\hline Tunder Amt .... & $48 \times 0$ & 359 & $18: 35$ & 34168 & 69 & \\
\hline $\begin{array}{l}\text { De sonderjydsk } \\
\text { Amter ialt.... }\end{array}$ & 30212 & 1451 & 18602 & $11006^{\circ}$ & & 40 \\
\hline $31 / 3 \quad 1925$ & & & & & & \\
\hline Aabenraa Amt ... & $3 \times 47$ & 88 & 2434 & 8633 & $5: 34$ & \\
\hline Haderslev Amt... & 12400 & $8: 30$ & 6797 & 3992 & 504 & \\
\hline Sunderborg Amt.. & 11874 & .374 & $79: 31$ & 27137 & 328 & \\
\hline Tunder Amt .... & 5080 & 351 & 2085 & 2969 & & 3 \\
\hline $\begin{array}{l}\text { Je sonderjydske } \\
\text { Amter ialt...... }\end{array}$ & $33 \div 201$ & 1643 & 19247 & 10591 & 1363 & \\
\hline
\end{tabular}

Ogsaa for Sparekassernes Vedkommende synes der at være en ret god Overensstemmelse med Statistikken over Gældsforholdene, naar man tager i Betragtning, at en Del af de $i$ foranstaaende Oversigt som Udlaan mod Gældsbevis opførte Beløb tillige er sikrede ved Pant i fast Ejendom, medens paa den anden Side Tallene for Udlaan mod Hypotek ogsaa omfatter Prioritetslaan i Købstadejendomme. Det sønderjydske Landbrugs indprotokollerede Gæld til Sparekasserne kan formentlig ansættes til ca. 17 Millioner Kroner. 
Med Hensyn til de sønderjydske Bankers og Bankfilialers Udvikling siden 1920 henvises til de Opiysninger, som herom er indeholdt i Bilag XII. I denne Forbindelse skal kun nævnes, at Bankernes samlede Udlaan i Form af Kassekrediter og paa Kontokurant ved Udgangen af 1924 beløb sig til 110 Millioner Kroner. Heraf falder efter et løst Skøn ca. Halvdelen paa Landbruget, og af dette Beløb vil antagelig ca. 40 Millioner vare sikrede ved Skadesløsbrev i faste Ejendomme. Ifølge den store statistiske Undersøgelse skal Bankernes Udlaan mod Pant i Landejendomme kun beløbe sig til 23,5 Mill. Kr.; men hertil maa lægges Størstedelen af de som Laan mod Sikkerhedshypotek opførte 13,3 Millioner, ligesom det stadig maa erindres, at det af Statistisk Departement bearbejdede Materiale ikke omfatter alle Landejendomme, men kun 90-95 pCt. af disse.

Af private Midler skal ifølge Statistikken indestaa 39,2 Mill. Kr. i de sønderjydske Landejendomme. Da der i de til Brug for Opgørelsen udsendte Skemaer ikke har været en særlig Rubrik for Laan fra offentlige Institutioner (Overformynderiet, Laanekassen for Sønderjylland osv.), vil en Del af de herhen hørende Gældsposter være opført und'er "Private".

Et yderligere Bidrag til Belysning af dette Spørgsmaal giver den tidligere omtalte Undersøgelse af Grundbøgerne for Ejendommene i 16 Landsogne (Bilag XVIII) samt for et Antal Ejendomme i en af de sønderjydske Købstæder. 
Pantegzeld pr. 31. December 1925.

\begin{tabular}{|c|c|c|c|c|c|c|}
\hline & \multicolumn{4}{|c|}{$\begin{array}{l}\text { 1702 Land- } 571 \text { Huse } \\
\text { ejendomme } \\
\text { i } 16 \text { Landsogne }\end{array}$} & \multicolumn{2}{|c|}{$\begin{array}{l}157 \text { lisbstad } \\
\text { ejendomme }\end{array}$} \\
\hline & $\begin{array}{c}\text { Mill. } \\
\text { Kr. }\end{array}$ & pCt. & $\begin{array}{l}\text { Mill. } \\
\mathrm{Kr} \text {. }\end{array}$ & pCt. & $\begin{array}{c}\text { Mill. } \\
\text { Kr. }\end{array}$ & pCt. \\
\hline $\begin{array}{l}\text { Kredit- og Hypotek- } \\
\text { foreninger ........ }\end{array}$ & 23,84 & 62 & 1,03 & 41 & 2,54 & $4 \pi$ \\
\hline Sparekasser........ & 2,20 & 6 & 0,23 & $y$ & 0,413 & 9 \\
\hline $\begin{array}{l}\text { Banker (Skadesloshre- } \\
\text { venes Paalydende) }\end{array}$ & 5,83 & 15 & $0, \overline{9} 9$ & 23 & 1.42 & 27 \\
\hline Andre Institutioner.. & 0,78 & 2 & 0,14 & 6 & 0,14 & 2 \\
\hline Private Midler.... . & 5,84 & 15 & 0,52 & 21 & 0,75 & 14 \\
\hline Tilsammen & 38,49 & 100 & 2,51 & 100 & 5,31 & 100 \\
\hline
\end{tabular}

Dersom man fra de 16 Sogne tor drage Slutninger med Hensyn til hele Landsdelen, vil de i sønderjydske Landejendomme indestaaende private Midler udgøre ca. 40 Millioner Kroner.

Den af Statistisk Departement for tagne Undersøgelse giver en ganske tilsvarende Fordeling af Gælden efter Kreditorgrupper for Landejendomme.

\begin{tabular}{|c|c|c|}
\hline \multirow{2}{*}{ • } & \multicolumn{2}{|c|}{$\begin{array}{l}\text { Indprotokolleret liæld for } \\
12688 \text { Landhrugsejen- } \\
\text { domme pr. } 15.0 \text { ktober } 1925\end{array}$} \\
\hline & Mill. kir. & $p C t$. \\
\hline \multirow{5}{*}{$\begin{array}{l}\text { Kredit- og Hypotekforcninger..... } \\
\text { Sparekasser................... } \\
\text { Banker ox Sikkerhedshyputeker... } \\
\text { Private Midler (og offentl. Institu- } \\
\quad \text { tioner) } \ldots \ldots \ldots \ldots \ldots \ldots \ldots \ldots\end{array}$} & 160,1 & 63 \\
\hline & 16,9 & 7 \\
\hline & 36,8 & 15 \\
\hline & 39,2 & $1 \overline{3}$ \\
\hline & 253,0 & 100 \\
\hline
\end{tabular}


Overensstemmelsen med Undersøgelsen af Grundbøgerne i 16 Sogne er umiskendelig, og for Ikke-Landbrugsejendomme i Landdistrikterne gælder det samme m. H. t. Sparekasser og Banker. Derimod ligger Tallene for Kredit- og Hypotekforeningslaan forholdsvis noget højere end i Sognestatistiken og tilsvarende lavere for private Laan.

Gaar man et Spadestik dybere i Undersøgelsen, viser det sig, at Gennemsnitstallene for hele Landsdelen dækker over ikke ubetydelige Forskelle fra Amt til Amt, ligesom i 1914 indtager Sønderborg Amt en Særstilling ikke alene med Hensyn til Gældens Størrelse, men ogsaa hvad angaar Gældsposternes Fordeling paa de forskellige Kategorier af Kredittorer. Her udgør Landbrugets samlede Behæftelse, ogsaa naar Hensyn tages til Aftægternes Kapitalværdi, en langt mindre Del af Ejendomsskylden end i de ovrige Amter. Takket være Jordens Bonitet, Ejendommens Størrelse og hele Driftsform har Bønderne i Sønderborg Amt og navnlig paa Als, haft bedre Betingelser for at overvinde Overgangstidens Vanskeligheder og modstaa Tidernes Tryk end deres Kaldsfæller i den øvrige Del af Sønderjylland. Sønderborg er da ogsaa det eneste Amt, i hvilket Landbrugets indprotokollerede Gæld - at dømme efter Undersøgelsen af de 3 Sogne - i Dag ikke er større i Kroner end 1914 i Mark.

Karakteristisk for Sønderborg Amt er endvidere den Omstændighed, at Sparekasserne i langt højere Grad end i de øvrige Amter har været i Stand til at 
gøre en Indsats paa Realkredittens Omraade, idet Sparekasselaanene her udgør 16 (efter Sogneundersøgelsen 17) pCt. af Landbrugets samlede Pantegæld mod 7 (henholdsvis (i) for hele Landsdelen.

Den grundbogsmassige Undersøgelse af Pantegælden i de 1i; Sogne bekræfter med de ovenomtalte Forbehold Resultaterne af den af Statistisk Departement efter Ejernes Opgivelser udarbejdede Opgorelse. De enkelte Sogne kan være mere eller mindre heldigt valgte som typiske Repræsentanter for det paagældende Amt, men en Sammenligning Sogn for Sogn med den store Undersøgelse viser en saa god Overensstenmelse, at man maa være berettiget til paa dette Grundlag at foretage en Opgorelse af det sønderjydske Landbrugs indprotokollerede Gæld pr. 15. Oktober 1925.

Kendskabet til Bankernes Balancer stadfæster for Depot- og Kautionslaanenes Vedkommende den store Undersogelses Resultater: Det er maaske ikke tilladt herfra uden videre at drage Slutninger $m$. $H$. $t$. Paalideligheden af de om Vekselgæld og anden Gæld givne Oplysninger; men efter stedkendte og sagkyndige Mænds Mening antages ogsaa denne Del af Materialet at svare ret godt til de virkelige Forhold.

Paa Grundlag af de saaledes ved Statistisk Departements Undersøgelse, ved Detailundersøgelsen af de 16 Sogne og de om sparekassernes og Bankernes Udlaan tilvejebragte Oplysninger kan Landbrugets samlede indprotokollerede og ikke indprotokollerede Gæld pr. 15. Oktober 1925 i store Træk opgøres saaledes: 
Den indprotokollerє de Gæld:

hredit- og Hypotekforeninger (Restgerld) ca. 166 Mill. Ki. Sinderjydske Sparekasser

" Banker og Bankfilialer - 41" " "

Andre Institutioner og private Midler - 46 "

Tilsammen: ra. 269 Mill. Kr.

Den samlede indprotokollerede Gæld er altsaa steget fra ca. 220 Mill. Mk. i 1914 til ca. 270 Mill. Kr., hvilket falder godt i Traad med Resultaterne af den grundbogsmæssige Undersngelse af Pantegalden i de 1i Sogne pr. 31. December 1914 og 31. December 192i, hvis Paalidelighed efter den Maade, paa hvilken Materialet er tilvejebragt, ikke kan omtvistes.

Ikke indprotokolleret Gald.

Depotlaan

Kautionslaan

Vekselgarld

Anden fidd ca. 7 Mill. Kr.

$-8 \% \pi$

$-X \| \#$

- $21 \gg "$

Tilsammen: 44 Mill, Kr.

Det sønderjydske Landbrugs Greld skulde saaledes ialt andrage godt $310 \mathrm{Mill}$. Kr.

Til Belysning af Spørgsmaalet, hvorledes den samlede indprotokollerede Gæld i de sønderjydske Landsdele har udviklet sig siden Genforeningen, foreligger der følgende Oplysninger fra Grundbogskontorerne: 


\begin{tabular}{c|c|c|c}
\hline \hline Aar & $\begin{array}{c}\text { Indførte Hypoteker } \\
\text { Mill. Kr. }\end{array}$ & $\begin{array}{c}\text { Edslettede } \\
\text { Hypoteker } \\
\text { Mlill. Kr. }\end{array}$ & $\begin{array}{c}\text { Nettotilvækst } \\
\text { Mill. Kr. }\end{array}$ \\
\hline 1920 & 76,5 & 6,7 & 75,7 \\
1921 & 160,6 & 13,3 & 147,3 \\
1922 & 79,7 & 14,6 & 65,1 \\
1923 & 64,8 & 15,6 & 49,2 \\
1924 & 48,7 & 16,4 & 32.3 \\
1925 & 70,1 & 21,6 & 48,5 \\
\hline & 500,4 & 82,3 & 418,1 \\
\hline
\end{tabular}

Den samlede indprotokollerede Gæld i Byerne og paa Landet i Sønderjylland udgør herefter, naar man fradrager 2 Mill. Kr. for Laan i offentlige Ejendommc, nominelt 416 Mill. Kr., som omtrentlig fordeler sig med folgende Beløb paa nedenstaaende Grupper af Kreditorer:

Kredit- og Hypotekforeninger (Hovedstol) 204 Mill. Kr. Sunderjydske Sparekasser Banker (Skadeslosbrevenes Paalydende) "110) " " Andre Institutioner Private ('a. 22" 2 10 $10 "$ $»$ (i) $" ~ "$ 416 Mill. Kr.

Den hertil svarende effektive Pantegæld vil ligge noget under 400 Millioner $\mathrm{Kr}$.

Vil man i store Træk danne sig et Helhedsbillede af den organiserede Kapitals Virkemidler i Sønderjylland efter Kapitalens Hjemsted, kommer man til folgende Resultat: 


\begin{tabular}{|c|c|c|c|c|}
\hline Institutioner & $\begin{array}{l}\text { Ind- } \\
\text { skud } \\
\text { Mill. } \\
\text { Kr. } \\
\end{array}$ & 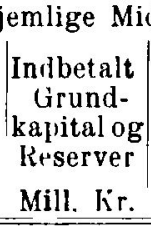 & $\begin{array}{c}\begin{array}{c}\text { Til- } \\
\text { sammen }\end{array} \\
\text { Mill. Kr. }\end{array}$ & $\begin{array}{c}\begin{array}{c}\text { Frem- } \\
\text { mede } \\
\text { Midler }\end{array} \\
\text { Mill. Kr. }\end{array}$ \\
\hline 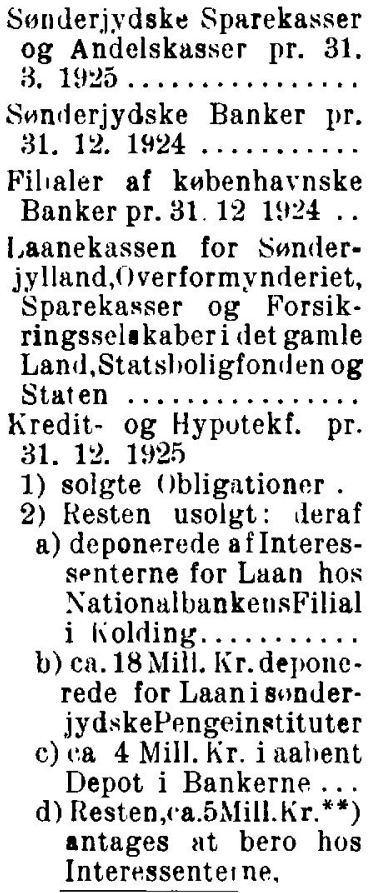 & $\begin{array}{l}44,7 \\
12,2\end{array}$ & ("a. $3,0^{*}$ ) & ca. $3 \times, 0$ & $\begin{array}{l}\left.\text { " } 15^{* *}\right) \\
\text {, } 185\end{array}$ \\
\hline & & & $\begin{array}{l}\text { ca. } 110 \\
\text { Ialt ca. }\end{array}$ & $\begin{array}{l}\text { ca. } 292 \\
0 \text { Mill. Kr. }\end{array}$ \\
\hline
\end{tabular}

-) Reserverne alene 1,6 Mill. Kr. Garantikapitalen skonsmassig ansat til 1,4 Mill. Kr.

*) Skmnsmæssig ansat. 
De hjemlige Indskudsmidler er, naar Mark onıregnes til Kroner efter Pari-Kurs, i Forhold til 1914 gaaet tilbage fra ca. 130 til 92 Millioner Kroner. Helc Nedgangen falder paa Sparekasserne, hvis Indskud er dalet fra 78 til 33 Mill. Kr., medens Bankernes og Bankfilialernes Indlaan fra Befolkningen samtidig er steget fra 43 til 57 Mill. Kr. Her staar vi ved det springende Punkt i Realkreditspørgsmaalet i Sønderjylland. Det er Manglen paa Sparekapital til Udlaan mod I. og II. Prioritet i faste Ejendomme, der gor Forholdene saa vanskelige. Hvad denne Tilbagegang betyder for Realkreditten i de sønderjydske Landsdele, forstaas først tilfulde, naar den ses paa Baggrund af Udviklingen i de nørrejydske Naboamter og paa Fyn:

Sparekasseindskud

i Millioner Kironer

31. 3.1909 31.3.191431.3.1924

De sonderjydske Amter ........

Vejle og Ribe Amter..........

Odense Amt .................

\begin{tabular}{rr|r|r} 
& \\
\cline { 2 - 3 } & 65,0 & $7 \times, 0$ & 30,2 \\
49,7 & 59,4 & 122,5 \\
$7 \times, 4$ & 117,7 & 229,8
\end{tabular}

Er Landsdelen praktisk talt blottet for Sparekasseindskud, er den til Gengæld rigelig forsynet med Bankmidler. De hjemlige Indlaan i vore Banker og Bankfilialer er forøget med 14 Mill. Kr., og den Kapital, som udefra gennem Bankerne er stillet til Raadighed for Erhverslivet i Nordslesvig, er samtidig steget fra (i til 87 Millioner Kroner. Vor Gæld til Laanekassen for Sønderjylland, Statsboligfonden, Staten, Overformynderiet, Sparekasser og Forsikringsselskaber i det gamle Land vil nogenlunde svare til, 
lyvad vi før Krigen skyldte til Institutioner af samme og lignende Art med Domicil sydfor den nuværende Grænse. Vore Pengeinstituters hjemlige Virkemidler udgor godt og vel 100 Mill. Kr. og de fremmede Midler, naar undtages Kredit- og Hypotekforeningslaan, ligeledes noget over 100 Mill. Kr. Gælden til Kredit- og Hypotekforeninger, som nu omfatter baade By- og Landejendomme, andrager ialt 224 Millioner Kroner mod 72 Millioner i 1914. Af disse 224 Mill. Kr. Obligationer, hvis kontante Værdi i Dag ligger omkring 175 Mill. Kr., er formentlig ca. 40 Millioner Kr. paa sønderjydske Hænder, deraf 18 Millioner belaant $i$ hjemlige Banker og sparekasser og 5 Millioner i Nationalbankens Filial i Kolding, medens Resten dels er solgt i Sunderjylland*) dels henligger usolgt og ubehæftet for Interessenternes Regning. Af de usolgte Obligationer er kun de i Nationalbankens Filial i Kolding belaante 5 Millioner opført i Oversigten. For saa vidt de er belaant i hjemlige Pengeinstitutter, vil Laanenes Belob findes blandt de til Indskud osv. i Banker og Sparekasser svarende Ldlaan, medens de Obligationer, som er ubehæftede i Interessenternes Eje, i denne Forbindelse kan betragtes som ikke udstedte.

Naar man ser paa den Cdvikling, som er skitseret $i$ det foregaaende, maa man under Hensyn til de store Onvæltninger, som har fundet sted, erkende, at Erhvervene i de sonderjydske Landsdele og ikke mindst Landbruget har haft store V'anskeligheder at

") Sonderjydske Banker og Sparekasser ligger for egen Regning inde med ca. 3 Mill. Kr. 
kæmpe med i de siden Genforeningen forløbne Aar. Det har været en i vide Kredse udbredt Opfattelse, at disse Omvæltninger, særlig Markvalutaens Sammenbrud, skulde have tilført Landejendonisbesidderne en saa betydelig Fordel, at de nu skulde være forholdsvis velstillede baade i Sammenligning med Forholdene i det gamle Land og med Tiden for Krigen, at den passive Kapitals Reprasentanter havde lidt ganske overordentlig under Markkatastrofen, kunde der jo ikke være Tvivl om. Den gunstige Bedøm-. melse af det sønderjydske Landbrugs økonomiske Stilling viser sig dog efter det ved de foretagne Undersøgelser oplyste ikke at holde Stik. Som der er gjort udførlig Rede for i tidligere Afsnit af dienne Unders:gelse, er Konverteringen af Landbrugets Gæld fra Mark til Kroner ikke sket paa saa fordelagtige Viikaar, som det almindeligvis er antaget. En stor Del af Markgælden fra Tiden for Krigen er bleven omplaceret til et forholdsvis højt Kronebeløb. Hvad der imidlertid har bragt Gælden op paa den Højde, den har i Dag, er de ugunstige Vilkaar, under hvilke Landbruget efter Krigen har maattet gaa i rang med Arbejdet paa Ejendommenes Istandsættelse, Besætningernes og Inventarets Komplettering og hele Driftens Genrejsning og Omlægning efter de nye Afsæiningsvilkaar. Dette store Arbejde har, scm oplyst, krævet en meget betydelig Kapitalanvendelse og medfort en foruroligende Vækst af Landbrugets Gæald fra Aar til Aar.

Forsaavidt man heraf vil drage den Slutning, at der er disponeret uforsvarligt, maa denne Opfattelse dog $\mathrm{i}$ det store og hele siges at bero paa en Fejlta 
gelse. De nordslesvigske Landmænd maatte gøre cn Indsats for at faa gennemført en til de forandrede Forhold svarende Drift af deres Ejendomme. De fulgte i saa Henseende de Raad, som fra all z sider blev givet dem; de kunde ikke se, at den Kapitalanbringelse, de foretog, vel var rigtig under Forudsætning af et stabilt Pris- og Valutaniveau, men som Forholdene har udviklet sig, maatte blive tabluringende. Der vil, hvor der af en hel Landsdels Befolkning tages fat paa saa store Opgaver, altid vare enkelte, der disponerer over Evne. Saadanne Tilfalde kan ogsaa paavises i Sønderjylland; men i det store og hele maa man mene, at den Kapitalanbringelse, som har fundet sted efter de givne Forudsatninger, var fuldt forsvarlig.

Ved Undersugelsen af den paa Landejendomme indprotokollerede Gæld i de 16 sogne kommer man til det Resultat, at denne, naar man omregner Mark til Kroner efter Parikurs og ser bort fra Kreditforeningsobligationernes Kurs og Rentefod, fra Tiden for Krigen indtil nu er steget med 42 pC. Der har utvivlsomt ogsaa i det gamle Land fundet en betydelig Greldsstigning Sted i idet samme Tidsrum. Forholdsvis betyder en procentvis lige Tilvækst i Gælden dog mere i de sønderjydske Landsdele, da det tyske Prisniveau for Landejendomme i 1914 laa højere end det danske. Efter de om Prioritetsgælden før Krigen foreliggende Oplysninger var denne oven i Købet særlig høj i Nordslesvig.

Det Billede, som Tallene giver af det sønderjydske Landbrugs Gæld, er derfor ikke lyst, i hvert Fald mørkere, end man paa Forhaand vilde være tilbøjelig 
til at antage. Forholdene ligger forskelligt fra Amt til Amt, fra Sogn til Sogn og fra Ejendom til Ejendom, men det kan ikke benægtes, at der findes et forholdsvis stort Antal af stærkt forgældede Landmænd, i Særdeleshed blandt dem, der har kobt Ejendom eller forceret Omlægningen og Gennemforelsen af en intensiv Drift under Hojkonjunkturen.

Men selv om Helhedsbilledet ikke er lyst, vilde det være urigtigt at betegne Stillingen som faretruende for Landbruget i sin Helhed. Hvad specielt Sammenligningen mellem Gælden nu og Galden før Krigen angaar, maa det erindres, at Ejendommene ikke alene er fort tilbage til samme Tilstand som tidligere, men delvis betydelig forbedrede. Pengenes Værdi er ogsaa mindre end før Krigen, saa den samme Behrftelse i Penge betyder ikke den samme Bebyrdelse, da Ejendommenes Værdi, baade Brugsog Handelsværdi, er større end for Krigen. Naar man derfor alene ser paa Gældens Storrelse i Forhold til Ejendommenes Værdi, maa Gældsbyrden vel nok betegnes som taalelig. Men anlægger man Rentabilitetssynspunktet, bliver Billedet morkere. Indtægterne er utvivlsomt storre end for Krigen, men L'dgifterne er steget relativt endnu mere. Dette gælder for Tiden ikke Foderstoffer og Kunstgodning, idet disse ganske vist udtrykt i Korn er dyrere end for, men derimod ikke udtrykt i Smør og Flæsk. Men L'dgifterne til Haandværksfrembringelser og overhovedet til alle Redskaber og Maskiner og Materialer, som repræsenterer en høj Arbejdsværdi, tynger uforholdsmæssigt. Skatterne er høje, de faste Afgifter til Elektricitetsselskaberne andrager forholdsvis store 
Beløb, ogsaa for den enkelte Ejendomsbesidder, og Gieldsrenten til Banker og Sparekasser er gennemgaaende saa høj, at det væsentlig forringer Udsigten for en rentabel Drift. Det maa derfor betegnes som i høj Grad paakrævet, at der skabes Mulighed for en Omplacering af den mest trykkende Del af Landbrugsgælden, saaledes at det sonderjydske Landbrug faar billigere og roligere Penge at arbejde med, end det for Øjeblikket har.

Kr. Refslund Thomsen. 